\title{
RADIOMETRIC DETECTION OF METABOLIC ACTIVITY OF PARACOCCIDIOIDES BRASILIENSIS AND ITS SUSCEPTIBILITY TO AMPHOTERICIN B AND DIETHYLSTILBESTROL
}

\author{
Edwaldo E. CAMARgo, Maria K. SATO, Gilda M. B. DEL NEGRo \& Carlos da Silva LACAZ.
}

\section{S U M M A $\mathbf{R} \mathbf{Y}$}

Paracoccidioidomycosis (South American blastomycosis) is a systemic disease, strikingly more frequent in males, caused by the dimorphic fungus Paracoccidioides brasiliensis. A radiometric assay system has been applied to study the metabolic activity and the effect of drugs on this fungus "in vitro". The $Y$ form of the yeast, grown in liquid Sabouraud medium was inoculated into sterile reaction vials containing the $6 \mathrm{~B}$ aerobic medium along with $2.0 \mu \mathrm{Ci}$ of ${ }^{14} \mathrm{C}$-substrates. Control vials, prepared in the same way, contained autoclaved fungi. To study the effects of amphotericin B (AB) $(0.1$ and $10 \mu \mathrm{g} / \mathrm{ml})$ and diethylstilbestrol (DSB) $(1.0,5.0$ and $10 \mu \mathrm{g} / \mathrm{ml})$ extra controls with live fungi and no drug were used. All vials were incubated at $35^{\circ} \mathrm{C}$ and metabolism measured daily with a $\mathrm{Bactec}$ instrument. ${ }^{14} \mathrm{CO}_{2}$ production by $P$. brasiliensis was slow and could be followed for as long as 50 days. AB at $10 \mu \mathrm{g} / \mathrm{ml}$ and DSB at $5 \mu \mathrm{g} / \mathrm{ml}$ inhibited the metabolism and had a cidal effect on this fungus. The results with DSB might explain the low incidence of the disease in females. This technique shows promise for studying metabolic pathways, investigating more convenient ${ }^{14} \mathrm{C}$-substrates to expedite radiometric detection and for monitoring the effects of other drugs and factors on the metabolism of $\mathbf{P}$. brasiliensis "in vitro".

KEY WORDS: Paracoccidioides brasiliensis; Radiometric assay; ${ }^{14} \mathrm{C}-$ Substrates; Amphotericin B; Diethylstilbestrol

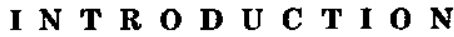

Paracoccidioidomycosis is a systemic disease, strikingly more frequent in males than females, caused by the dimorphic fungus Paracoccidioides brasiliensis. Despite the various studies on the biochemical composition of both its $Y$ and $M$ forms (12) and several attempts at improving culture media (15), P. brasiliensis grows very slowly in all media so far used for its cultivation "in vitro".
Since the early 1970 's, a radiometric method, which measures ${ }^{14} \mathrm{CO}_{2}$ evolved from a convenient reaction system, has been used for rapid detection of bacterial growth in clinical microbiology (7). Today the method is widely used as a clinical tool in many hospitals for fast detection and drug susceptibility testing of most common clinical pathogens (8). The method was extended to study the fastidious organisms of ge- 
CAMARGO, E. E.: SATO. M. K.: DEL NEGRO. G. M. B. \& LACAZ. C. da S. - Radiometric detection of metabolic activity of Paracoccidioides brasiliensis and its susceptibility to amphotericin B and diethylstilbestrol. Rev. Inst. Med. trop. Sāo Paulo, 29:289-294, 1987.

nus Mycobacterium with very promising results (4). This led, in turn, to clinical application with mycobacteria, which are now becoming routine in several centers (18). However, the radiometric method has not been used with P. brasiliensis. Because of its high sensitivity, this method might be a useful tool to better understand metabolic requirements of this organism, as it did with mycobacteria $(3,6)$.

The purpose of this investigation was to determine the feasibility of detecting the metabolic activity of $\mathbf{P}$. brasiliensis with the radiometric method using a commercially available radioactive medium, and the effect of factors that might interfere with is metabolism "in vitro".

\section{MATERIALS AND METHODS}

\section{Preparation of Fungi:}

The yeast form $(\mathrm{Y})$ of $\mathbf{P}$. brasiliensis, strain 18, was obtained on solid Sabouraud medium (Difco) from Laboratório de Micologia Médica do Instituto de Medicina Tropical de Săo Paulo. The fungi were transferred to liquid Sabouraud medium (Difco), and incubated at $35^{\circ} \mathrm{C}$ for two weeks. The fungal suspension was centrifuged at $1,200 \mathrm{xg}$ and the supernatant discarded. The pellet was ressuspended with $10 \mathrm{ml}$ of sterile saline and the centrifugation procedure repeated 3 times. The microorganisms were counted directly using a Neubauer chamber. The final suspension was diluted with sterile saline to yield $2 \times 10^{7}$ microorganisms per $\mathrm{ml}$.

\section{Reaction System:}

The reaction system for ${ }^{14} \mathrm{CO}_{2}$ detection consisted of $30 \mathrm{ml}$ of the $6 \mathrm{~B}$ aerobic medium in a $50 \mathrm{ml}$ multidose sterile vial along with $2.0 \mathrm{uCi}$ of ${ }^{14} \mathrm{C}$-substrates (Johnston Laboratories) and 1.0 $\mathrm{ml}$ of fungal suspension. All vials were prepared at least in triplicate. Control vials were prepared in the same way, but with autoclaved fungi added. When studying the effect of drugs on the fungal metabolism, extra controls with live fungi and no drug were always prepared for comparison.

\section{Drugs:}

The effects of amphotericin B (Squibb) and diethylstilbestrol (Sigma) on the metabolism of P. brasiliensis were studied. Amphotericin B was diluted with sterile saline so that the desired concentrations of $0.1 \mu \mathrm{g} / \mathrm{ml}$ and $10 \mu \mathrm{g} / \mathrm{ml}$ were delivered in $0.6 \mathrm{ml}$. Similarly, diethylstilbestrol was diluted with methanol so that concentrations of $1.0,5.0$ and $10 \mu \mathrm{g} / \mathrm{ml}$ were delivered in $75 \mu$ l. Control vials for diethylstilbestrol contained the same volume of methanol.

At the end of the incubation period of the experiments, the fungi from vials containing 10 $\mu \mathrm{g} / \mathrm{ml}$ amphotericin $\mathrm{B}$ and from vials containing $5.0 \mu \mathrm{g} / \mathrm{ml}$ diethylstilbestrol were recovered after centrifugation at $1,200 \mathrm{xg}$, washed 3 times with sterile saline, inoculated separately into new $6 \mathrm{~B}$ medium vials and incubated at $35^{\circ} \mathrm{C}$ for two weeks.

\section{Radiometric Measurement:}

All vials were incubated at $35^{\circ} \mathrm{C}$ and the ${ }^{14} \mathrm{CO}_{2}$ produced by fungal metabolism was measured radiometrically. The measurement device, a Bactec $301 \mathrm{~B}$ (Johnston Laboratories), consisted of an ionization chamber, a vacuum pump. a set of sterile sampling needles and a logarithmic scale up to 1,000 index units ( 100 index units $=25$ nanocuries of ${ }^{14} \mathrm{C}$ activity). The needles penetrated the rubber stopper of the multidose sterile vial and the ${ }^{14} \mathrm{CO}_{2}$ was aspirated into the ionization chamber under vacuum. The atmosphere in the vials was replaced with room air filtered through a $0.22 \mathrm{~nm}$ pore size filter membrane. Radioactivity was measured by the ionization chamber as index units. More details of the measurement procedure have been published elsewhere (5). The vials were sampled daily for as long as $\mathbf{5 0}$ days. Resuits were expressed either as index units for the metabolic activity experiments or as percent activity of control vials for the drug experiments. Background readings of the Bactec ranged from zero to 8 index units. All readings above 12 units were considered as positive for growth.

\section{Pilot Experiments:}

Pilot experiments with the $M$ form of this fungus were performed as describe above. The 
CAMARGO, E. E.; SATO, M. K.; DEL NEGRO, G. M. B. \& LACAZ, C. da S. - Radiometric detection of metabolic activity of Paracoccidioides brasiliensis and its susceptibility to amphotericin $B$ and diethylstilbestrol. Rev. Inst. Med. trop. São Paulo, 29:289-294, 1987.

colonies were scrapped from solid Sabouraud medium, suspended in sterile saline, diluted to approximately $2 \times 10^{7}$ organisms per ml, inoculated into the $6 \mathrm{~B}$ aerobic medium and incubated at room temperature. The vials were sampled daily for 7 days.

\section{RESULTS}

Metabolic activity of $P$. brasiliensis in $6 \mathrm{~B}$ aerobic medium was slow. After 2 days incubation, ${ }^{14} \mathrm{CO}_{2}$ production was fairly constant at about 40 index units per day up to 20 days. Then, it fell off to reach background levels by 50 days. Figure 1 represents the differential weekly ${ }^{14} \mathrm{CO}_{2}$ production, that is, the amount of ${ }^{14} \mathrm{CO}_{2}$ produced within a given week. As shown in the figure, differential metabolism peaked at 2 weeks. In every week, ${ }^{14} \mathrm{CO}_{2}$ sampling was performed daily for 5 days, starting over again at the beginning of the next week, Figure 2 represents the cumulative ${ }^{14} \mathrm{CO}_{2}$ production, that is, the addition of the differential ${ }^{14} \mathrm{CO}_{2}$ production within a given time interval,

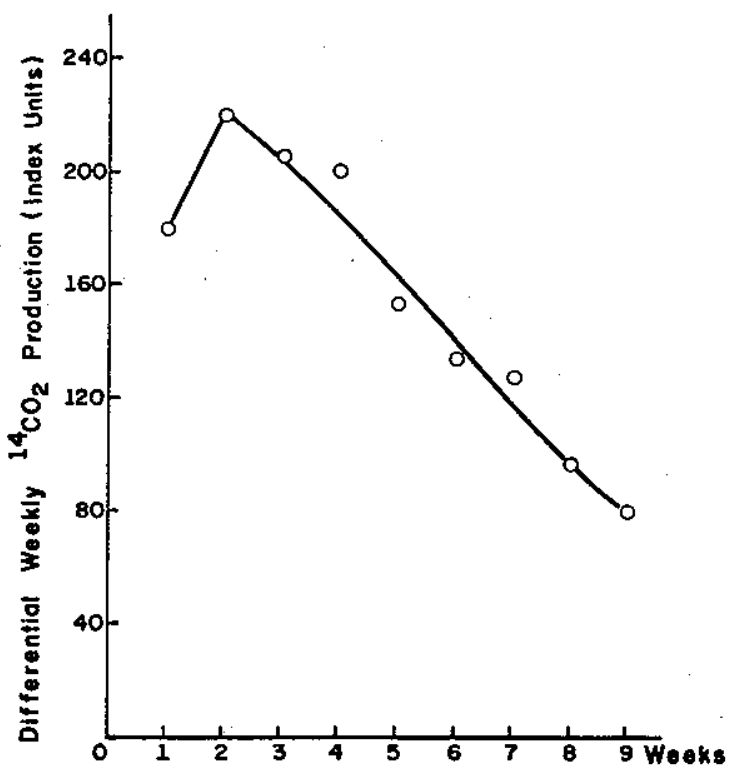

Fig. 1 - Differential weekly ${ }^{14} \mathrm{CO}_{2}$ production by the $\mathrm{Y}$ form of $P$. brasiliensis in $6 \mathrm{~B}$ aerobic medium. There was a peak activity at two weeks, with a progressive decline to background levels. Index units difference from one experimental vial to another was negligible. Each experiment was repeated at least twice.

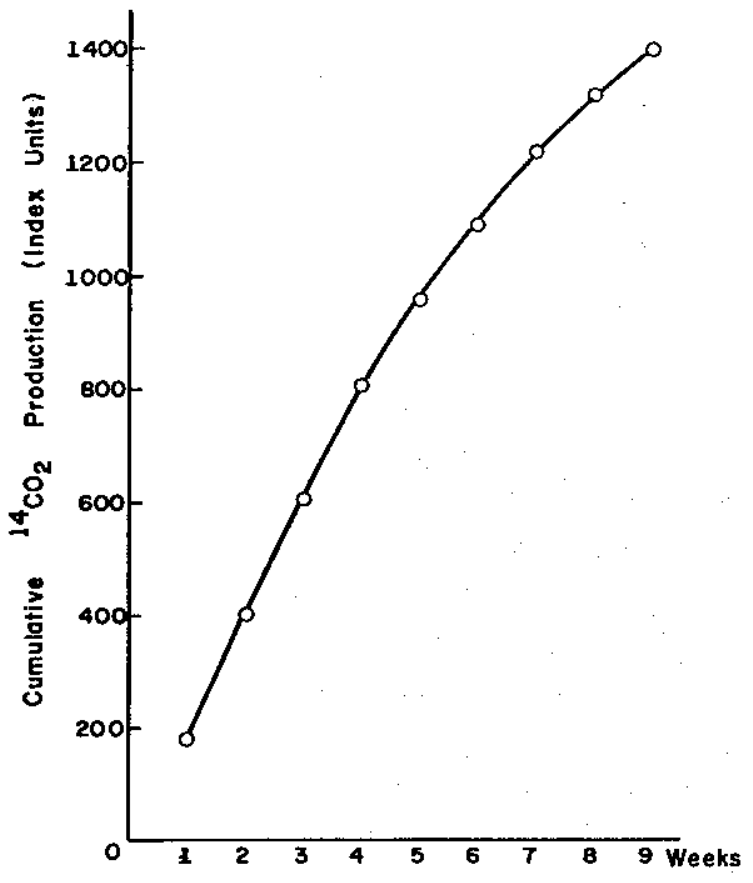

Fig. 2 - Cumulative weekly ${ }^{14} \mathrm{CO}_{2}$ production by the $\mathrm{Y}$ form of $P$. brasiliensis in $6 B$ aerobic medium. Index units difference from one experimental vial to another was negligible. Each experiment was repeated at least twice.

Amphotericin B at $0.1 \mu \mathrm{g} / \mathrm{ml}$ was unable to block the metabolic activity of $P$. brasiliensis. After the first week, vials with the drug displayed about $60 \%$ of the ${ }^{14} \mathrm{CO}_{2}$ production of control vials, increasing to about $80 \%$ at two weeks and $\mathbf{9 5 \%}$ at three weeks. At $10 \mu \mathrm{g} / \mathrm{ml}$, however, metabolism was inhibited and dropped to $35 \%$ of the control vials by the end of the first week and to less than $10 \%$ at two weeks (Figure 3).

Diethylstilbestrol at $1.0 \mu \mathrm{g} / \mathrm{ml}$ was unable to inhibit the metabolism of $\mathbf{P}$. brasiliensis; there was no difference between control vials and hormone vials. At $5.0 \mu \mathrm{g} / \mathrm{ml}$, the metabolism dropped to $35 \%$ of control vials after one week, and to about $5 \%$ at two weeks. There was no metabolism at all when hormonal concentration was $10 \mu \mathrm{g} / \mathrm{ml}$ (Figure 4).

Fungi recovered from vials containing $10 \mu \mathrm{g} /$ $\mathrm{ml}$ amphotericin $\mathrm{B}$ and from vials containing $5.0 \mu \mathrm{g} / \mathrm{ml}$ diethylstilbestrol showed no metabolic activity after two weeks incubation. 
CAMARGO, E. E.; SATO, M. K.; DEL NEGRO, G. M. B. \& LACAZ, C. da S. - Radiometric detection of metabolic activity of Paracoccidioides brasiliensis and its susceptibility to amphotericin B and diethylstilbestrol. Rev. Inst. Med. trop. São Paulo, 29:289 294, 1987.

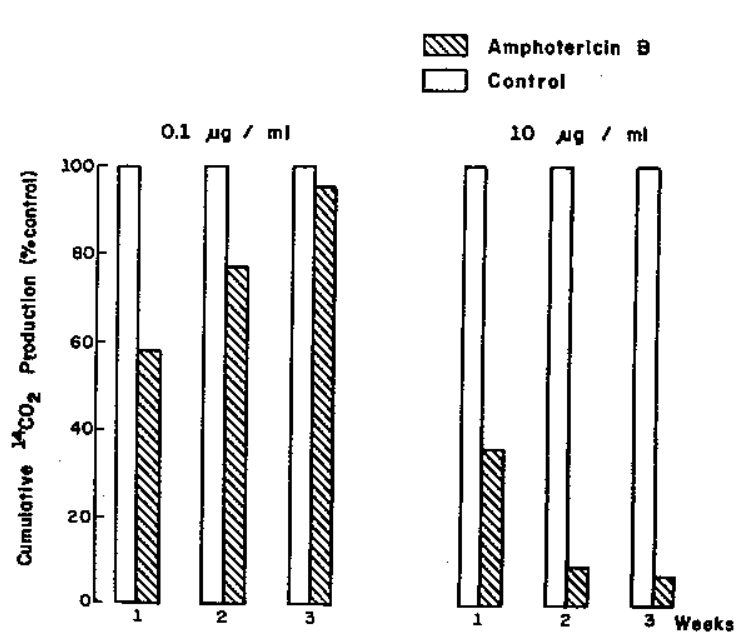

Fig. 3 - Effect of amphotericin $\mathrm{B}$ on the ${ }^{14} \mathrm{CO}_{2}$ production of the $\mathrm{Y}$ form of $\mathrm{P}$. brasiliensis in $6 \mathrm{~B}$ aerobic medium. At 0.1 $\mu \mathrm{g} / \mathrm{ml}$, there was no inhibition of metabolic activity of the fungus. At $10 \mu \mathrm{g} / \mathrm{ml}$ three was marked inhibition of metabolism, specially after 2 and 3 weeks incubation. Index units difference from one experimental vial to another was negligible. Each experiment was repeated at least twice.

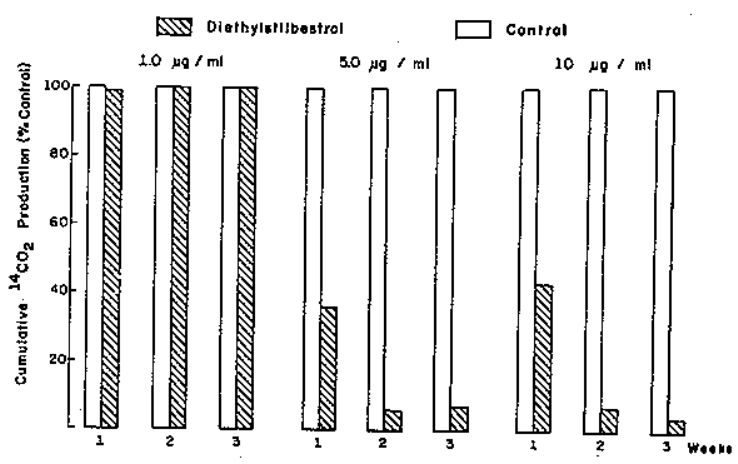

Fig. 4 - Effect of diethylstilbestrol on ${ }^{14} \mathrm{CO}_{2}$ production by the $\mathrm{Y}$ form of $\mathrm{P}$. brasiliensis in $6 \mathrm{~B}$ aerobic medium. At 1.0 $\mu \mathrm{g} / \mathrm{ml}$ there was no effect. At 5.0 and $10 \mu \mathrm{g} / \mathrm{ml}$ there was marked inhibition of metabolic activity, more pronounced after 2 and 3 weeks incubation. Index units difference from one experimental vial to another was negligible. Each experiment was repeated at least twice.

There was no ${ }^{14} \mathrm{CO}_{2}$ production from vials containing the $\mathbf{M}$ form of $\mathbf{P}$. brasiliensis.

\section{DISCUSSION}

Radiometric studies on metabolic activity of $P$. brasiliensis have not been reported. The present investigation has demonstrated that by using the commercially available $6 \mathrm{~B}$ aerobic me- dium, which contins ${ }^{14} \mathrm{C}$-substrates, radiometric detection of ${ }^{14} \mathrm{CO}_{2}$ production by this fungus is feasible within a few days. In contrast, the conventional culture technique in Sabouraud-agar takes 20 to 30 days for growth detection. Therefore, the radiometric method has the potential for fast, effective screening of new ${ }^{14} \mathrm{C}$-substrates, more adequate growth media and in the investigation of other factors that might interfere with the metabolic activity of this fungus "in vitro". However, when compared to other fastidious microorganisms such as Candida albicans (11), Mycobacterium tuberculosis (6) and Mycobacterium lepraemurium (2-4), metabolic activity of P. brasiliensis as measured by ${ }^{14} \mathrm{CO}_{2}$ evolved from $6 \mathrm{~B}$ aerobic medium was considerably slower. It is conceivable that the $6 \mathrm{~B}$ medium, although adequate to support growth of a broad spectrum of the most common clinical pathogens, is not entirely suited for this fungus. Also, the unlabeled substrates in the medium might compete with the ${ }^{14} \mathrm{C}$-substrates for oxidation. Or, the ${ }^{14} \mathrm{C}$-substrates provided by the manufacturer and which most likely include $\left(\mathrm{U}_{-}{ }^{14} \mathrm{C}\right)$ glu cose, ${ }^{14} \mathrm{C}$-formate and one of the simpler $\left(\mathrm{U}_{-}{ }^{14} \mathrm{C}\right)$ $\mathrm{L}$-amino acids, may not be adequate for the metabolic requirements of $\mathbf{P}$. brasiliensis.

The search for the best ${ }^{14} \mathrm{C}$-substrate to monitor the metabolism of a given microorganism may be a difficult process. Ideally, the simplest medium able to support its growth, and free of each of the unlabeled substrates to be tested in radioactive form, should be used. Different ${ }^{14} \mathrm{C}$-substrates would then be added separately to the medium along with the microorganism and a simple yes-or-no answer obtained after incubation. This was the procedure used to deter. mine that $\left(\mathrm{U}-{ }^{14} \mathrm{C}\right)$ glycerol, $\left(\mathrm{U}_{-}{ }^{14} \mathrm{C}\right)$ acetate, $\left(1-{ }^{14} \mathrm{C}\right)$ fatty acids and ${ }^{14} \mathrm{C}$-formate were more effective than $\left(\mathrm{U}^{14} \mathrm{C}\right)$ glucose, $\left(\mathrm{U}_{-}{ }^{14} \mathrm{C}\right)$ pyruvate and $\left(\mathrm{U}_{-}{ }^{14} \mathrm{C}\right)$ glycine with $M$. tuberculosis and $M$. lepraemurium (except ${ }^{14} \mathrm{C}$-formate) $(2-4,6)$. Biochemical studies have shown that $P$. brasiliensis utilizes fatty acids such as oleic, patmitic, and linoleic (12) and that growth can be stimulated by amino acids such as asparagine and glycine (9). One can then speculate that perhaps by using separately these substrates labeled with carbon-14, higher ${ }^{14} \mathrm{CO}_{2}$ outputs and faster results would be obtained. 
CAMARGO, E. E.; SATO, M. K.; DEL NEGRO, G. M. B. \& LACAZ, C. da S. - Radiometric detection of metabolic activity of Paracoccidioides brasiliensis and its susceptibility to amphotericin B and diethylstilbestrol. Rev. Inst. Med. trop. Sāo Paulo, 29:289-294, 1987.

The effect of steroid hormones on the growth of $P$. brasiliensis was reported by MUCHMORE et al. (16) who found that at $25^{\circ} \mathrm{C}$ and $37^{\circ} \mathrm{C}$ estradiol and diethylstilbestrol in concentrations of $10 \mu \mathrm{g} / \mathrm{ml}$ completely inhibited the growth of this fungus. However, testosterone and cholesterol in the same concentration showed no effect on any of the isolates tested. The rationale for their investigation was the striking preponderance of male patients with the disease: in our institution (13) and in other series $(1,17)$, ratios male/female of 13:1 have been found. Such a phenomenon cannot be explainded by different exposure rates to the fungus, since the incidence of delayed hypersensitivity to intradermal paracoccidioidin is the same in both sexes. MUCHMORE et al. (16) did not mean to imply that the simple inhibitory effects of natural estrogen were responsible for the low incidence of the disease in females, since the concentrations used in their investigation were much higher than those that occur in the human body. The present study has confirmed their findings, even at a lower concentration of $5 \boldsymbol{\mu g} / \mathrm{ml}$ of diethylstilbestrol. Because of the cidal effect of $5 \mu \mathrm{g} / \mathrm{ml}$ of diethylstilbestrol, it is conceivable that, not taking into account other defense mechanisms, this hormone alone would provide a basis for explanation of a low incidence of the disease in females. It is worthy of mention the study of STADALNIK et al. (19) on a very similar disease, coccidioidomycosis. After the 1977 dust storm in the Sacramento Valley, which randomly exposed an entire population to spores of Coccidioides immitis, an epide mic of the disease occurred and 12 patients were referred to their hospital. The striking fact was that 11 of these patients were males and only one female. In an randomized exposure such as this, a 1:1 ratio would be expected, and a 11:1 ratio could only be understood if the female population was protected, possibly by estrogens.

Effective levels of amphotericin $B$ range from 2.0 to $4.0 \mu \mathrm{g} / \mathrm{ml}$ of blood $(10,14)$. The cidal effect of $10 \mu \mathrm{g} / \mathrm{ml}$ described in the present inves tigation represents less than the clinically effective dose, when one considers the heavy inoculum of $2 \times 10^{7}$ fungi $/ \mathrm{ml}$, a concentration not found under clinical conditions. This suggests that either the $6 \mathrm{~B}$ medium, not being completely suited for P. brasiliensis, makes the organism more susceptible to drug action or that its "in vivo" effect may be hindered by partial inactivation of some sort (10).

This investigation has demonstrated that the metabolic activity of $\mathbf{P}$. brasiliensis and the effects of factors that might interfere with its metabolism can be studied with a radiometric system. However, the slow ${ }^{14} \mathrm{CO}_{2}$ production using the commercially available $6 \mathrm{~B}$ aerobic medium strongly suggests that the reaction system here utilized is not optimal. Investigation of other ${ }^{14} \mathrm{C}$-substrates, such as fatty acids and amino acids, that might be more adequate for the metabolic requirements of this organism, seems to be warranted in future experiments.

\section{RESUMO}

\section{Detecção radiométrica da atividade metabólica do Paracoccidioides brasiliensis e da sua sensibilidade à Anfotericina $\mathrm{B}$ e ao Dietilestilbestrol}

A paracoccidiodomicose (blastomicose sulamericana) é uma doença sistêmica muito mais freqüente no sexo masculino, causada pelo fungo dimórfico Paracoccidioides brasiliensis. Um sistema radiométrico foi utilizado para estudar a atividade metabólica e o efeito de drogas sobre este fungo "in vitro". A forma $Y$ do fungo, cultivada em Sabouraud líquido, foi inoculada em frascos estéreis contendo o meio aeróbio $6 \mathrm{~B}$, juntamente com 2,0 uCi de substâncias marcadas com carbono-14. Frascos-controle, preparados da mesma forma, foram inoculados com fungos autoclavados. Para estudar os efeitos da anfotericina $\mathrm{B}$ (AB) $(0,1$ e $10 \mu \mathrm{g} / \mathrm{ml})$ e do dietilestilbestrol (DEB) $(1,5$ e $10 \mu \mathrm{g} / \mathrm{ml})$, controles adicionais foram preparados, contendo fungos viáveis mas năo a droga. Todos os frascos foram incubados a $35^{\circ} \mathrm{C}$ e o metabolismo medido diariamente com uma máquina Bactec. A produção de ${ }^{14} \mathrm{CO}_{2}$ pelo $P$. brasiliensis foi lenta e pôde ser acompanhada por 50 dias. Concentraçōes de $10 \mu \mathrm{g} / \mathrm{ml}$ de AB e $5 \mu \mathrm{g} / \mathrm{ml}$ de DEB inibiram o metabolismo e tiveram efeito fungicida. Os resultados com DEB poderiam explicar a baixa incidencia da doença em mulheres. Esta técnica é promissora para estudar as vias metabólicas, investigar substâncias marcadas mais adequadas para tornar mais rápida a detecçāo radiométrica do fungo e para acompanhar os efeitos de outras drogas 
CAMARGO, E. E.; SATO, M. K.; DEL NEGRO, G. M. B. \& LACAZ, C. da S. - Radiometric detection of metabolic activity of Paracoccidioides brasiliensis and its susceptibility to amphotericin B and diethylstilbestrol. Rev. Inst. Med. trop. Sāo Paulo, 29:289-294, 1987.

e fatores sobre o metabolismo do $\mathbf{P}$. brasiliensis "in vitro".

\section{REFERENCES}

1. BRASS, K. - Observaciones sobre la anatomia patolo gica, pathogenesis y evolución de la paracoccidiomycosis. Mycopathogia (Den Haag), 37: 119-138, 1969.

2. CAMARGO, E. E.; LARSON, S. M.; TEPPER, B. S. \& WAGNER JR., H. N. - Radiometric measurement of me tabolic activity of Mycobacterium lepraemurium. Appl. Microbiol., 28: 452-455, 1974

3. CAMARGO, E. E,; LARSON, S. M.; TEPPER, B. S. \& WAGNER JR., H. N. - Radiometric studies of Mycobacterium lepraemurium. Int. J. Leprosy, 44: 294-300, 1976.

4. Camargo, E. E,; Kertcher, J. A.; LARSon, S. M. TEPPER, B. S. \& WAGNER JR., H. N. - Radiometric measurement of diferential metabolism of fatty acid by mycobacteria. Int. J. Leprosy, 50: 200-204, 1982.

5. CAMARGO, E. E. \& LARSON, S. M. - Radiomicrobiology. In: ROCHA, A. F. G. \& HARBERT, J. C., ed. Textbook of nuclear medicine: basic science. Philadelphia, Lea \& Febiger, 1984. p. 339-350.

6. CUMMINGS, D. M.; RISTROPH, D.; CAMARGO, E. E.; LARSON, S. M. \& WAGNER JR., H. N. - Radiometric detection of the metabolic activity of Mycobacterium tuberculosis. J. nuel. Med, 16: 1189-1191, 1975.

7. DeBLANC JR., H. J.; DeLAND, F. H. \& WAGNER JR., H. N. - Automated radiometric detection of bacteria in 2,967 blood cultures. Appl. Microbiol., 22: 846-849, 1971.

8. DeBLANC JR., H. N.; CHARACHE, P. \& WAGNER JR., H. N. - Automated radiometric measurement of antibiotic effect on bacterial growth. Antimicrob. Agents Chemother., 2: 360-366, 1972.

9. GILARDI, G. L. - Nutrition of systemic and subcutaneous pathogenic fungi. Bact. Rev., 29: 406-424, 1965.
10. GOODMAN, L. S. \& GILMAN, A. - The pharmacological basis of therapeutics. 3rd. ed. New York, McMillan, 1975. p. 1236-1238.

11. HOPFER, R. L.; MILLS, K. \& GRÖSHEL, D. - Improved blood culture medium for radiometric detection of yeasts J. elin. Microbiol., 9: 448-449, 1979

12. KANETSUNA, F.; CARBONELL, L. M.; MORENO, R. E \& RODRIGUEZ, J. - Cell wall composition of the yeast and mycelial forms of Paracoccidioides brasiliensis. $\mathbf{J}$ Bact., 97: 1036-1041, 1969.

13. LACAZ, C. S. - South American blastomycosis. An. Fac. Med. S. Paulo, 29: 1-120, 1955.

14. LACAZ, C. S.; ULSON, C. M. \& SAMPAIO, S. A. P. Açāo in vitro da anfotericina $B$ sobre o Paracoccidioides brasiliensis. Rev. paul. Med., 54: 357-360, 1959.

15. LACAZ, C. S. - Diagnóstico micológico. In: DEL NEGRO, G.; LACAZ, C. S. \& FIORILLO, A. M., ed. - Paracoceidioidomicose. Blastomicose sul-americana. Sảo Paulo, Sarvier, 1982. p. 245-251.

16. MUCHMORE, H. G.; MCKOWN, B. A. \& MOHR, J. A. - Effect of steroid hormones on the growth of Paracoccidioides brasiliensis. In: PARACOCCIDIODOMYCOSIS. PAN AMERICAN SYMPOSIUM, 1., Medellin, 1971. Proceedings. Washington, P. A. H. O., 1972. p. 300-304. (Scientific Publication No 254)

17. PEÑA, C. - Deep mycotic infections in Colombia: a clinopathologic study of 162 cases. Amer. J. elin. Path., 47: 505-520, 1967.

18. SIDDIQUI, S. H.; HWANGBO, C. C.; SHLCOX, V.; GOOD, R. C.; SNIDER, D. E. \& MIDDLEBROOK, G. - Rapid radiometric method to detect and differentiate Mycobacterium tuberculosis/M. bovis from other mycobacterial species. Amer. Rev. resp. Dis., 130: 634-640, 1984.

19. STADALNIK, R. C.; GOLDSTEIN, E.; HOEPRICH, P. D.; SANTOS, R. A. L. dos \& LEE, K. K. - Diagnostic value of gallium and bone scans in evaluation of extrapulmonary coccidioidal lesions. Amer. Rev. resp. Dis., 121: 673-676, 1980 .

Recebido para publicação em 19/1/87. 